Anat. Labor. of Prof. H. SETO, Tohoku University, Sendai.

\title{
On the Sensory Innervation of the Rectum in Cat.
}

\author{
猫直腸の知覚神経分布飞就て。 \\ Teruo TAKAHASHI, Toru NUMATA, \\ Gozaburo SUGAMATA and Yoshiaki TOKUMITSU \\ 高橋輝男, 沼田 透, 菅又剛三郎 と徳光義明.
}

(Received February 6, 1956.)

At this laboratory, we have recently succeeded in proving the existence of sensory fibres and their terminations in the mucous membrane of the caudal parts of the rectum - SETO in man, SHIMODA in dog and NIIZUMA in bat. Formerly, SOTELO has reported on the sensary terminations in the muscularis and the mucous membrane of the colon and the rectum of animals and human embryos, but his findings obtained with preparations stained with CAJAL's method and his explanations based on them are not free of points we find hard to admit.

The authors of this paper had their interest aroused by this problem and for the sake of comparative anatomical research, took their materials from the cat rectum, fixed them in $10 \%$ neutral formol for a long time, cut them into $40 \mu$ transverse frozen sections and having stained them with SETO's silver impregnation method, studied the large series of tissue preparations thus obtained under a microscope with minute care. The part of the cat rectum we have studied was somewhat different from that studied by the predecessors cited above, consisting in a more proximal part of it rather distant from the anus, that is, the rectal part correspondiug between the pars cervicalis of the bladder and the caudal end of the pars interglandularis of the male urethra. In fact, sensory fibres and their terminations were found even in such a proximal part of the rectum of cat. Studying our findings in comparison with those obtained by SHIMODA concerning canine, by NIIZUMA on bat and by SETO on human recta, we succeeded in arriving at some interesting results, as reported in the following.

\section{Individual Findings.}

The rectal wall of cat is nothing different from that of man in essential structure but in size it is much smaller. Little fold formation is observable in the mucous membrane in the part beneath the pars cervicalis vesicae, but when we go farther caudalwards, several longitudinal folds gradually growing in size appearance. The intestinal crypts of the 
mucous membrane contain very abundant goblet cells, as was the case with the canine rectum, and the propria consists of a reticular connective tissue rich in free cells, particularly in lymphocytes and is richly provided with blood capillaries and veins. It is of interest that small veins are seen often running transversally through the intercryptal zones.

The muscularis mucossae consists of distinct inner circular and outer longitudinal layers. The submucosa around it is made of a loose connective tissue containing a little fat tissue and has comparatively large blood vessels in it, but occupies only a very limited area, when compared with the same in human rectum, except where it forms the ground of the mucous folds, where it is rather well developed. Here and there in this submucosa, we find considerably large-sized solitary lymph follicles, each of which often reaches deep into the basis of the submucosa and is surrounded by a connective tissue capsule. The tops of these follicles protrude into the propria through the muscularis, so that the crypts there are partially in a state of collapse, losing perceptibly in height, and sometimes lymphocytes are found migrated out into the epithelium.

The tunica muscularis also is composed of an inner circular and an outer longitudinal layers, but their development is far poorer than that in human rectum. This tunica does not extend into the mucous folds. It comes into connecticn with its surrounding orgar s through an adventitia of loose connective tissue, but in the cranial part, its ventral side is provided with a tunica serosa with a thin subserosa.

What was most surprising in my study was that a rather large number of sensory fibres and their terminations were found in the mucous membrane of the cat rectum. These sensory fibres are rperesented as myelinated thick fibres, which run in company with very fine vegetative fibres from the loose connective tissue adventitia forming the outermost jayer of the rectal wall through the muscularis into the submucosa, then through the muscularis mucosae into the propria to form their terminations therein. These sensory endings are always in the form of free endings of thick fibres and are thus readily distinguishable histologically from the STÖHR's terminal reticulum of vegetative fibres.

According to SOTELO, sensory terminations are found in the tunica muscularis of the colon and the rectum of many animals including man. SATO has ascertained the existence of sensory endings - in a very limited number indeed - in the muscularis of the human stomach. Such observations seem to indicate the possible presence of sensory terminations in the tunica muscularis of the other parts of the alimentary tract, but none has been found to date in the muscularis of the duodenum and the small intestine. Neither could we find them in the tunica muscularis of the feline rectum. 
Sensory terminations have been sometimes detected in the submucosa and the muscularis mucosae of the alimentary tract, for example, in both the membranes of the duodenum of human embryos by SETO and UTSUSHI and in the muscularis mueosae of the rectum of dog by SHIMODA. But in bat (NIIZUMA) or human (SETO) rectum, they were found neither in the submucosa nor in the muscularis mucosae.

In the rectum of cat too, sensory terminations are only very rarely found in the muscularis mucosae not to speak of the submucosa, the sensory fibres in most cases forming their terminations only upon reaching the propria. So, it may be seen that the sensory terminations in the alimentary tract are formed in different layers of the wall according to the kinds of animals and the positions in the tract.

The sensory fibres in the cat rectum, upon penetrating into the connective tissue of the propria, soon lose their myelin sheaths and then pass over into their terminations. The terminations here are either branched or unbranched, and their terminal fibres, as in human (SETO), canine (SHIMODA) or the bat rectum (NIIZUMA), are smooth-surfaced and of nearly uniform diameter throughout, showing little change in size in their often slightly wavy courses, and diffusing rather widely in the propria, taper off into sharp points reaching the vicinity of the intestinal crypts. Scarcely any fibre is found to reach further into the epithelium to end as intraepithelial fibre.

Complex branched terminations have been found by SETO in the hunman rectum, but in our sections of the feline rectum, we found nothing more complex than simple branched terminations consisting of at most 4-5 terminal fibres. There are, however, somewhat higher

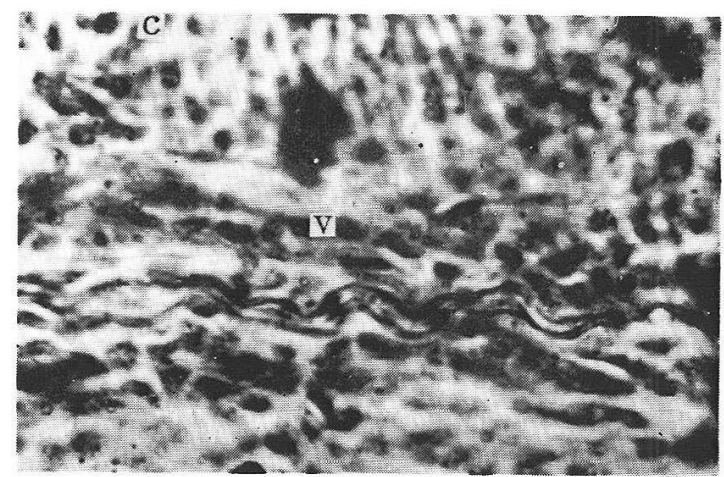

Fig. 1. A bifurcated sensory termination found in the intermediate layer of the propria of the rectum of a cat. Transverse section. $v$ small vein, $c$ intestinal crypt; sharp points of the 2 terminal fibres were not represented. SE'TO's impregnation. Photo $\times 200$. 
in complexity than those in the bat rectum (NIIZUMA). Not rarely, thick sensory fibres are seen running transversally along the small veins passing through the intermediate layer of the propria, frequently forming their terminations therein. 'Typical examples of such terminations may be seen in Figs. 1 and 2. In the former, a single stem fibre is seen bifurcating

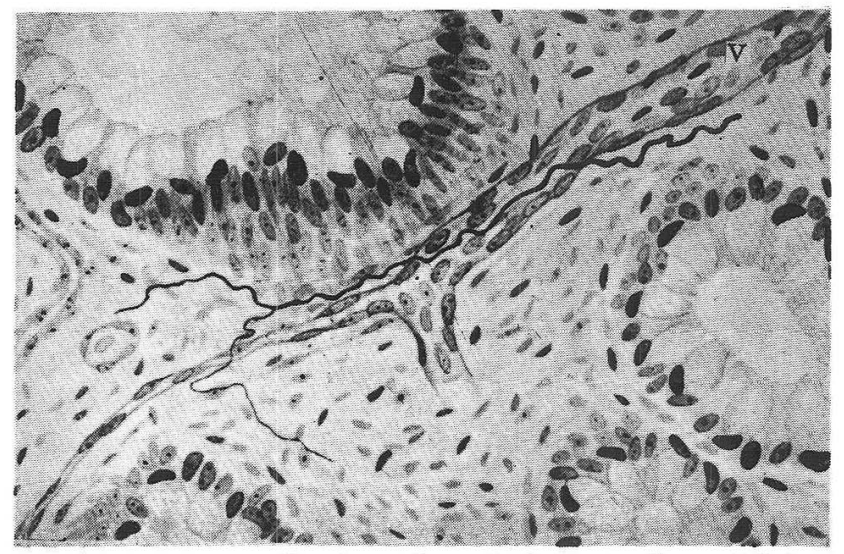

Fig. 2. Ditto. $v$ small vein, $c$ intestinal crypt. Same staining. $\times 150$.

into two parallel branches, which run peripheralwards between two veins, accompanying a few vegetative fibres, and come to sharp ends a typical bifurcated termination of the simplest type. In Fig. 2, we see another bifurcated termination formed alongside a vein running across the intermediate zone of the propria, with its two branches perceptibly different in size.

Unbranched terminations are illustrated in Figs. 3 and 4 . Here we find demyelinated thick sensory fibres running slightly wavy courses to taper off into sharp points, forming typical unbranched terminations. These terminal fibres never penetrate further into the epithelium of the crypts, to end intraepithelially. In Fig. 4, the sensory fibre is seen accompanying some fine vegetative fibres and their terminal reticulum.

Figs. 5 and 6 show branched terminations composed of $3-4$ terminal branches. The one in Fig, 5 is rather widely diffused and the thick terminal branch seen in the right-hand upper corner continues its course far beyond the right-hand margin of the figure. Fine vegetative fibres and their terminal reticula are seen running along these terminal branches. One of the other terminal branches is very fine and ends sharply in the close vicinity of an intestinal crypt. It does not, however, penetrate into the epithelium. This termination has been photographed under rather strong mangification, so that the fine fibres and the terminal 


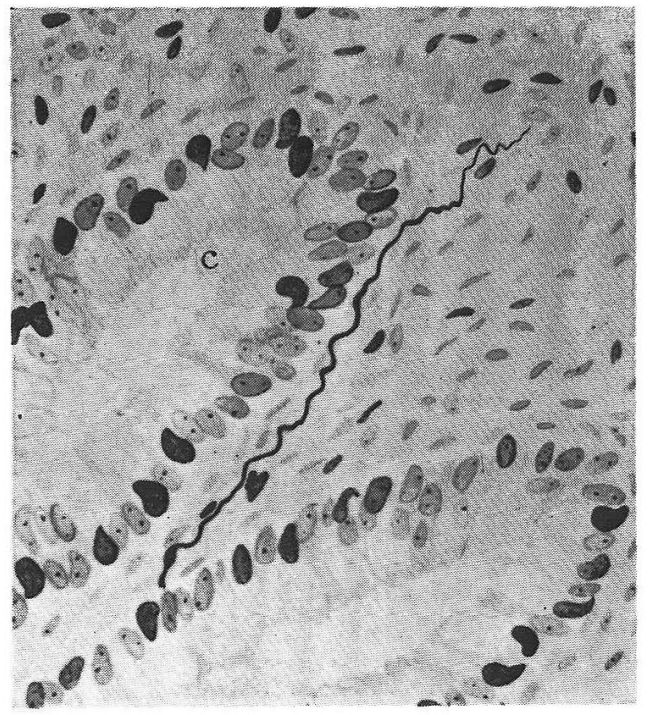

Fig. 3. An unbranched sensory termination ending in a sharp point found in the propria of the rectum of a cat. Transverae section. $c$ intestinal crypt. Same staining. $\times 150$.

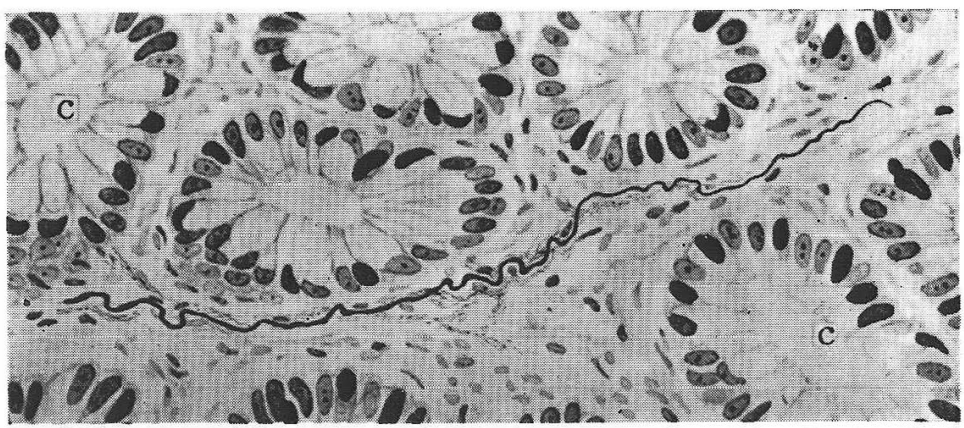

Fig. 4. An unbranched sensory termination acompanied by the terminal reticulum $(t)$ found in the propria of the rectum of a cat. Transverse section. $c$ intestinal crypt. Same staining. $\times 150$.

reticula formed of very minute fibres are not adequately distinguishable as we would wish. Fig. 6 shows a branched termination of 4 terminal branches formed in the rather broad connective tissue propria lying betwen the intestinal erypts. The terminal branches taper off into sharp points around a crypt each. These may appear as running further into the epithelium of the crypts, but in reality, they were found to end subepithelially. Fine vegetative fibres and their terminal reticula are seen diffusing along these terminal branches too. 


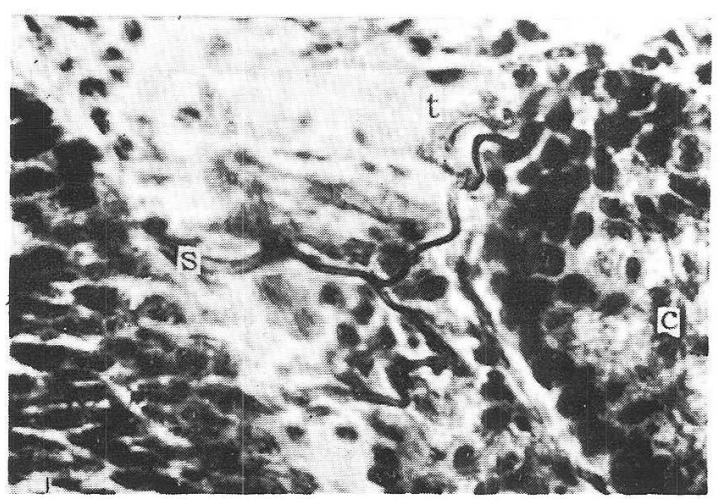

Fig. 5. A simple branched sensory termnation found in the propria of the rectum of a cat. Transverse section. $c$ intestinal crypt, $s$ stem fibre; the further course of a thick terminal branch in the right-hand upper corner was not developed, $t$ vegetative terminal reticulum was not adequately represented. Same staining. Photo $\times 200$.

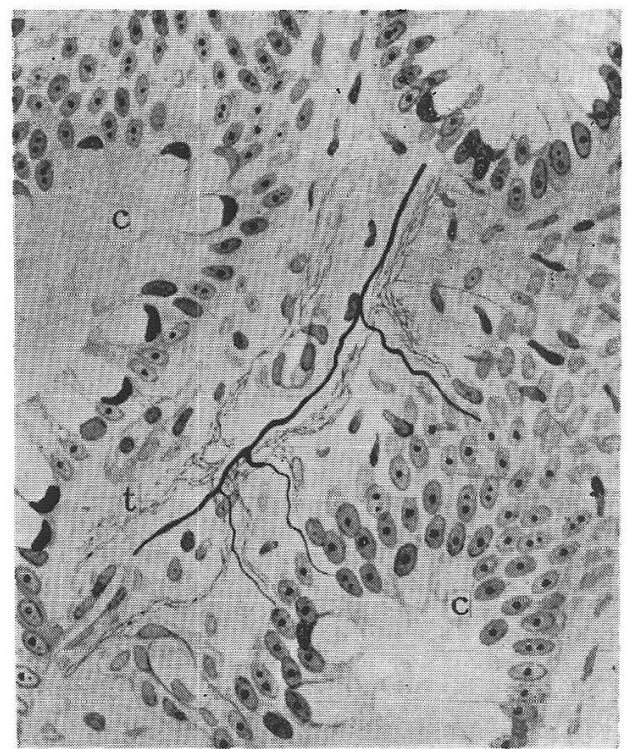

Fig. 6. Ditto. Sensory terminal branches end in a sharp point each; $c$ intestinal erypt, $t$ vegetative terminal reticulum. Same staining. $\times 150$.

As described in the above, sensory fibres and their terminations are found in a rather large quantity in the rectum of cat. The terminations 
are either in the form of unbranched or of simple branched type and are always formed in the propria. Their terminal branches consist in fibres showing little change in size during their courses and tapering off gradually, end in sharp points in the close vicinity of the intestinal crypts.

\section{內 容 自 抄。}

猫直腸にも人間及他動物に於ける様に知覚線維並びに其終末が発見され る。終末様式は非分岐性及び単純な分岐性終末で表わされ，之等は専ら固 有膜内飞形成され，其終末枝は表面平滑な線維から成り，其先端は尖鋭状 となって多くは腸隠窝の周辺に終る.

\section{References.}

Niizuma : Arch. hist. jap. 9 (1955). - Seto: Arb. Anat. Inst. Sendai 23 (1940). - Advance of Medicine. (jap.) 5 (1948). - Folia anat. jap. 28 (1956). Shimoda : Arch. hist. jap. 7 (1954). - Sotelo: Z. Zellforsch. 41 (1954). Utsushi : Tohoku J. exp. Med. 60 (1954). 